Отримано: 24 травня 2018 р.

Прорецензовано: 30 травня 2018 р.

Прийнято до друку: 03 червня 2018 р.

e-mail:vsm@ce.net.ua

DOI: $10.25264 / 2311-5149-2018-9(37)-4-10$
Гріненко А. Ю. Сучасні проблеми енергетичної безпеки України в трансформаційному світі. Наукові записки Національного університету «Острозька академія». Серія «Економіка»: науковий журнал. Острог : Вид-во НаУОА, червень 2018. № 9(37). C. 4-10.

\author{
Гріненко Андрій Юрійович, \\ кандидат економічних наук, доцент \\ директор Товариства з обмеженою відповідальністю «Кліар Енерджі»
}

\title{
СУЧАСНІ ПРОБЛЕМИ ЕНЕРГЕТИЧНОЇ БЕЗПЕКИ УКРАЇНИ У ТРАНСФОРМАЦІЙНОМУ СВІТІ
}

\begin{abstract}
У статті проаналізовано основні тенденції розвитку енергетичного сектора Украӥни в сучасних геополітичних умовах. Проведено оцінку стану і динаміки рівня енергетичної безпеки України впродовж останніх 25 років. Енергетика в сучасному світі є найважливішим складовим елементом економіки будь-якої краӥни. У статті закцентовано увагу на тому, щь держави світу поділяють на ті, у кого є в наявності енергетичні ресурси в достатній кількості для бездефіцитного використання, та ті, які мають їх у недостатній кількості, й окремі краӥни, які стурбовані падінням попиту і иін на окремі види ресурсів. Як висновок у статі констатовано, щяо енергетична безпека є проблемою для всіх країн Світу. Одні залежать від пропозичії, інші від попиту, їх економіка, як правило, тримається на доходах від продажу енергетичних ресурсів.
\end{abstract}

Ключові слова: енергетична безпека, енергозбереження, енергоефективність, загрози, ризики, індикатори, енергопостачання, краӥни-імпортери, країни-експортери.

\author{
Гриненко Андрей Юрьевич, \\ кандидат экономических наук, дочент \\ директор Общества с ограниченной ответственностью «Клиар Енерджи»
}

\section{СОВРЕМЕННЫЕ ПРОБЛЕМЫ ЭНЕРГЕТИЧЕСКОЙ БЕЗОПАСНОСТИ УКРАИНЫ В ТРАНСФОРМАЦИОННОМ МИРЕ}

В статье проанализированы основные тенденции развития энергетического сектора Украины в современных геополитических условиях. Проведена оценка состояния и динамики уровня энергетической безопасности Украины на протяжении последних 25 лет. Энергетика в современном мире является важнейшим составным элементом экономики любой страны. В статье акиентируется внимание на том, что государства Мира делятся на тех, у кого есть в наличии энергетические ресурсы в достаточном количестве для бездефичитного использования, и отдельные страны, которые обеспокоены падением спроса и цен на отдельные виды ресурсов. Как вывод в статье констатируется, что энергетическая безопасность есть проблемой для всех стран Мира. Одни зависят от предложения, другие от спроса, их экономика, как правило, держится на доходах от продажи энергетических ресурсов.

Ключевые слова: энергетическая безопасность, энергобережливость, энергоэффективность, угрозы, риски, индикаторы, энергоснабжение, страны-импортеры, страны-экспортеры.

\author{
Andrii Hrinenko, \\ Ph.D. in Economics, Assistant Professor, \\ Director of the Limited Liability Company «Clear Energy»
}

\section{MODERN PROBLEMS OF ENERGY SECURITY OF UKRAINE IN THE TRANSFORMATIONAL WORLD}

The article analyzes the main tendencies of the energy sector development in modern geopolitical conditions of Ukraine. The energy security level dynamics in Ukraine during the last 25 years has been assessed. Energy in the modern world is an essential component of any country's economy. The article focuses on the fact that states of the world are divided into those who have sufficient energy resources for their internal use, those who lack energy resources and individual countries, concerned about falling demand and prices for certain types of resources. As the conclusion it is stated that energy security is a problem for all countries of the world. Some depend on supply, others on demand, their economy, as a rule, rests on the income from the sale of energy resources.

Key words: energy security, energy conservation, energy efficiency, threat, risk, indicators, energy supply, importing states, exporting states.

Постановка проблеми. В умовах взаємної залежності держав в енергетичній сфері необхідний такий стан міжнародних відносин у вирішенні проблеми енергетичної безпеки, у межах якого будуть створені умови для попередження серйозних міжнародних кризових ситуацій і конфліктів, пов’язаних із видобут- 
ком, торгівлею, транспортуванням і споживанням енергоресурсів, а також із зниження гостроти наявних протиріч в умовах загострення міжнародної конкуренції за енергоносії. Енергетична залежність практично всіх країн світу (одних від попиту інших від пропозиції) веде до значної девальвації рівня життя населення цих країн. При такому підході забезпечення енергетичної безпеки є сприятливим соціальним фактором. Аналіз останніх досліджень і публікацій. Сучасні дослідження проблеми енергетичної безпеки як правило розглядають виходячи з трьох поглядів - дефіциту ресурсів, ціни ресурсів і конкуренції на ринку ресурсів. На радянському просторі, у зв'язку із існуванням нереально низьких цін на енергоносії проблема енергетичної безпеки практично була вирішена, як на рівні громадян тодішньої країни, так і на рівні всіх країн соціалістичного табору. Сьогоднішня проблема безпеки обумовлена високою енергомісткістю виробництва, залежністю від імпорту нафти і газу та неефективністю інфраструктури енергетичного ринку, монопольною залежністю України на ринку енергоносіїв, низьким рівнем енергозбереження.

Забезпечення енергетичної безпеки держав і різні аспекти їх дослідження викладені у працях багатьох вітчизняних і зарубіжних учених, зокрема Є. Боброва, В. Бушуєва, М. Ковалко, Т. Коцко, О. Охріменко, Є. Приймакова, Ю. Свірчевської, А. Сухорукова, М. Хурси. Однак, незважаючи на широке поле проведеного дослідження, неенергетична безпека, особливо протягом останніх років, отримала нові загрози міждержавні конфлікти, обмеження реалізації енергоносіїв і формування монопольних зон їх реалізації, розгляд спірних питань, падіння рівня споживання та формування природних замінників ресурсів і т.д.

Мета дослідження полягає у визначенні специфіки економічних та політичних факторів і ролі енергетичної стратегії держави , яка безпосередньо впливає на створення умов енергетичної безпеки країни. Завдання дослідження викладено відповідно до поставленої мети: визначення загроз енергетичній безпеці національній економіці України в її трансформаційному стані.

Виклад основного матеріалу. Утворення десятків незалежних країн на межі XX - XXI - го століть привело до формування неринкових відносин на пострадянському і постсоціалістичному просторах. На відміну від ринкових традицій, що склалися протягом віків у стосунках між державами, новоутворені незалежні країни почали спонтанно формувати ціни на ресурси та на окремі товари і послуги. Наявність в одних незалежних новоутворених країнах надлишку енергетичних ресурсів, а також їх дефіцит в інших сприяв зростанню економічних загроз тих і інших: перші зробили «наркозалежною» всієї економіки країни від умов реалізації, інші стали залежними від дефіциту енергоресурсів. Країни, що стали на шлях ринкових трансформацій мали недостатній науковий, творчий і технічний потенціал щодо зниження рівня енергоємності виробництва, енергозбереження та нетрадиційних форм використання енергії, та за умови низьких цін на енергоносії у цьому власне не було й потреби. Незважаючи навіть на те, що протягом останніх десятиліть точилися не лише ринкові баталії, а навіть розгорталися безпосередньо криваві війни як за ринки енергоносіїв, так і за джерела їх отримання. Саме цього часу з боку США й інших країн, які мали недостатню кількість ресурсів, був здійснений виклик про перерозподіл ринку енергоносіїв. Враховуючи що 1/6 їх знаходиться на території Росії, велика кількість їх у деяких країнах Азії (Іран, Ірак, Кувейт тощо) була внесена пропозиція визнати енергоресурси цих країн власністю всіх країн світу. Хоча дана пропозиція не знайшла позитивного відгуку а ні в ООН, а ні серед більшості країн світу, боротьба за ринки ресурсів ще більше загострилася, через вихід одного із основних гравців ринку Росії на освоєння нічийних територій Арктики й Антарктиди, значними коливанням цін на ринках енергоресурсів, залежності виходу нових гравців на ринок ресурсів, через політичний тиск інших країн і зміною технології видобутку, яка не прийнятна для середнє європейського шельфу (розрив пластів). Зростання кризи енергоспоживання країн, які розвиваються, розпочалося на межі століть і продовжує визначати світовий попит на енергоносії, не лише привела до глобального енергоспоживання, але й серйозно вплинула на міжнародну торгівлю енергоресурсами. Загальне зростання числа учасників міжнародних відносин у сфері енергетики привело до ускладнення цих відносин, зростанню конкуренції на поставку енергоносіїв і за активи видобутку в державах, багатих енергоресурсами. В умовах, коли вирішення проблеми забезпечення енергетичної безпеки стало все більше залежати від явищ і процесів, які відбуваються в усьому світі, зросло значення забезпечення глобальної енергетичної безпеки.

Водночас серед спеціалістів продовжується дискусія як про суть поняття «енергетична безпека», так і про методи їх забезпечення. Враховуючи значення енергоресурсів для економічного розвитку держав світу та кожного громадянина цих держав і для міжнародної безпеки, очевидно що високе не лише наукове, але й політичне та практичне значення цієї дискусії.

На думку багатьох учасників дискусії, загрозами системі забезпечення енергетичної безпеки є: значні коливання цін на світових ринках енергоресурсів; вразливість енергетичних ринків щодо перебоїв в енергопостачанні; розвиток обхідних маршрутів транспортування енергоресурсів на євразійському просторі; непрозора приватизація, експансія та монополізація внутрішніх ринків енергоресурсів іноземними транснаціональними енергетичними компаніями; збільшення кількості природних катаклізмів і відповідних втрат для енергетичної інфраструктури країни; висока зношеність енергетичної інфраструктури; недостатнє використання високоефективних екологічно безпечних технологій та обладнання, що може 
призвести до подальшого забруднення і деградації природного середовища, збільшення соціальної напруги і зростання економічних збитків у галузях, залежних від стану довкілля [1, с. 175].

Більшість експертів на вказаному етапі притримуються думки, згідно з якою практично всі країни світу як експортери, так і імпортери енергоресурсів, а також такі країни, як Україна - країни енергетичного транзиту, взаємозалежні щодо питань забезпечення енергетичної безпеки. Зокрема, російський академік Є. М. Приймаков зазначив, що в поняття «енергетична безпека» вкладають, насамперед, таке: «Не однобічна гарантія поставок, які трактують енергетичну безпеку багато західних представників. Безпека має забезпечуватися «потрійною» гарантією: поставок від країн виробників; транспортування з боку країн, по території яких вона відбувається; попиту від країн-споживачів» [2, с. 148].

Проблема забезпечення енергетичної безпеки складна і багатогранна, в ній переплетені політична, соціальна, технічна, економічна, екологічні складові. Та найбільш вагомим, на нашу думку, $є$ політична складова, оскільки сьогодні питання енергетичної безпеки регулюються не скільки законами ринкової економіки, скільки геополітичними інтересами. Енергоресурси перетворилися в потужний політичний інструмент, а світовий ринок енергоресурсів став ареною зіткнення політичних інтересів.

Багато країн використовують енергосировинний фактор, як спосіб реалізації власних інтересів в міжнародних відносинах. Це і за будь-яких умов обмеження експорту, політичний тиск і шантаж та на кінець пряме збройне втручання. Все це ми спостерігаємо сьогодні у відношеннях основного імпортера енергоносіїв в Україну - від Росії, та за наявністю власних запасів енергоносіїв Україна може по-перше диверсифікувати ринок енергоносіїв, а по-друге наростити видобуток власних енергоресурсів, та відповідно до Ст. 13. Конституції України повернути їх у власність народу.

За даними Рис. 1 в Україні видобувається понад 20 млрд куб. м газу, що складає 63\% від потреб на споживання цього енергоносія, оскільки з них лише 12,5 млрд куб. м - державний видобуток. Та суть енергетичної безпеки з балансу газу полягає в тому, що за майже п'ятдесят років Україна не лише не збільшила видобуток газу, а навпаки скоротила його втричі. I це при значній енергетичній залежності від імпорту газу.

«Ми ще в 1970-80 роках добували 60 і більше мільярдів кубів газу. Сьогодні ледве-ледве держава видобуває 12,5 млрд. I коли я чую, у тому числі й від інших політичних сил, що Україна добуває 20 млрд куб. м газу і цього достатньо населенню, то я хочу сказати, що 12,5 млрд - це державний газ, а 8 млрд - це приватний газ, який дали можливість добувати приватним компаніям і знищували українську газодобувну галузь», - заявив Гройсман [3].

Україна має потенціал скоротити споживання газу, який використовується для опалення в житловому секторі, до 4 млрд куб. м, завдяки проведенню енергоефективних заходів. Щорічно весь житловий сектор України споживає близько 18 млрд куб. газу. В Уряді заявили, що, якби не слабка енергоефективність і втрати в тепломережах, то кількість споживаного газу в ідеалі може скоротитися на 9,5 млрд куб. м [3].

Так, станом на 27 травня 2018 року за даними Укртрансгазу, запаси газу в підземних сховищах України збільшилися до 9,4 млрд куб. м, отже, наповненість газосховищ сягнула $30 \%$, оскільки на території материкової України залишилося 12 сховищ, активною ємністю майже 31 млрд куб. м.

При цьому в даних за 27 травня 2018 року зазначено, що в Україну за добу надійшло зі Словаччини 30,80 млн куб. м, з Угорщини - 6,95 млн куб. м, із Польщі - 2,52 млн куб. м газу. Як бачимо в переліку імпортерів газу знаходяться країни, які не являються виробником газу, вони здійснюють реекспорт, отримуючи від цього політичну ренту, яку платить Україна.

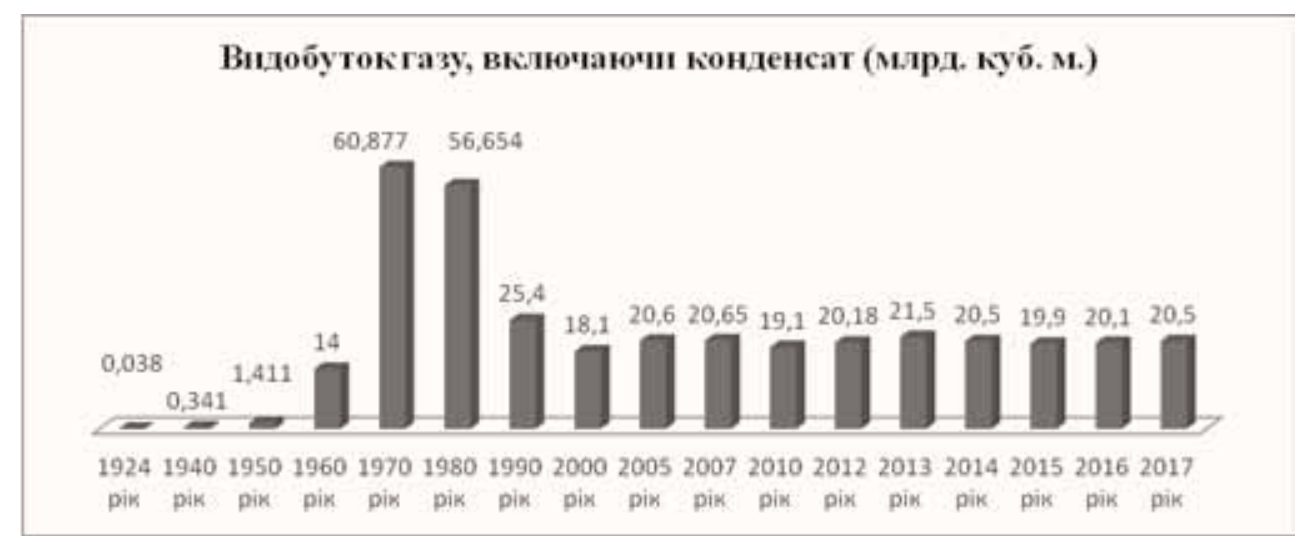

Рис. 1. Видобуток газу, включаючи конденсат (млрд куб. м) (розроблено автором за [6]) 
У 2017 році сумарне закачування газу в сховища перевищило його відбір на 2,7 млрд куб. м, тоді як у 2016-му році відбір перевищив закачування на 2 млрд куб. м. Відбір за підсумками 2017 року становив 6,4 млрд куб. м, закачування - 9,1 млрд куб. м [4].

Україна - найдешевший транзитер російського газу. Ціна транзиту у 2008 році становила $\$ 1,7$ за тисячу кубометрів на сто кілометрів при європейській ставці \$4. Втрати для України у 2008 році склали \$2,1 млрд. Стало відомо з джерел Нафтогазу, що рішенням Стокгольмського арбітражу транзиту, російський Газпром зобов’язаний виплатити «Нафтогазу» понад \$4,6 млрд [5].

Україна сьогодні має можливість суттєво зменшити споживання газу через упровадження енергозберігаючих технологій і використання інших природних джерел енергії.

Серед таких джерел може бути електроенергія, виробництво якої в Україні стрімко диверсифікується. Але за наявності в Україні значної кількості гідроелектростанцій на малих ріках, виробництво електроенергії, як свідчать дані рис. 2, можна було б збільшити до рівня 1990 року.

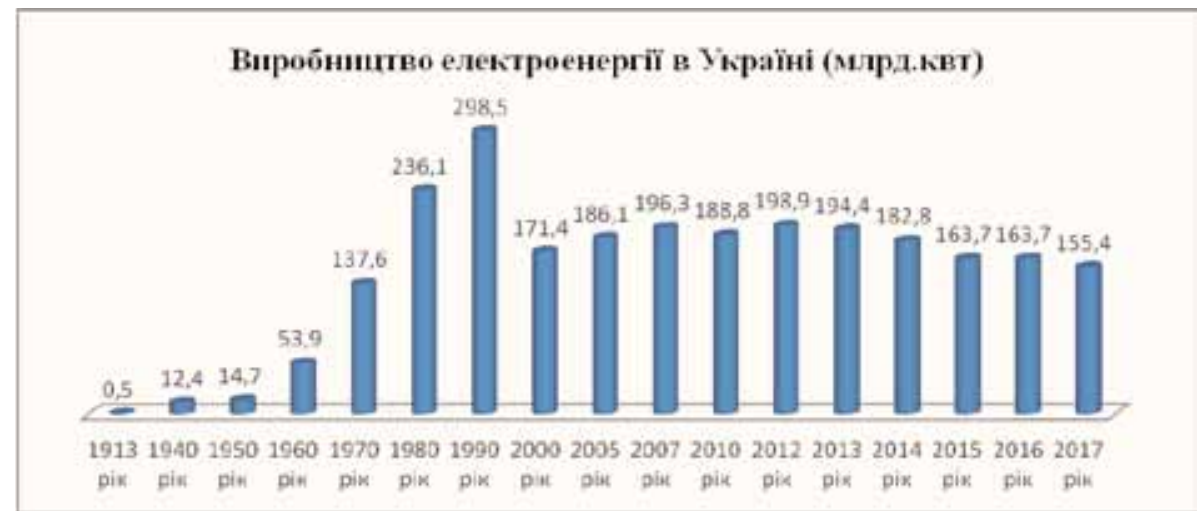

Рис. 2. Виробництво електроенергії в Україні (млрд квт) (розроблено автором за [6])

Тобто майже у два рази можна збільшити виробництво електроенергії, особливо у весняно-осінній період, коли на ріках відбувається розлив. Найпотужнішим джерелом водної енергії $є$ гірські ріки Карпат.

Водночас намагання будь-що використовувати атомну енергетику веде не лише до екологічних катастроф, а й до подальшої енергетичної залежності та зростання енергетичних ризиків, адже паливо (твели) для такого типу реакторів атомних станцій виробляють лише в Росії. Замінники інших виробників у такому виробництві непридатні.

$€$ ще одне джерело енергії, зокрема і для виробництва електроенергії - це використання вугілля і для теплових електростанцій. Як видно з рис. 3, видобуток вугілля в Україні за останні півстоліття скоротився більше, ніж у шість разів, при чому ставку у видобутку вугілля протягом цього часу було зроблено на Донецький басейн.

Так, у зв'язку із агресією Росії й утворенням невизнаних ЛНР і ДНР спостерігаємо падіння вуглевидобутку, в зоні бойових дій сформувався дефіцит марок вугілля, серед яких АТ і Т. Україна почала експортувати вугілля з Африканського й Американського континенту, а енергокомпанії змушені підписувати імпортні контракти.

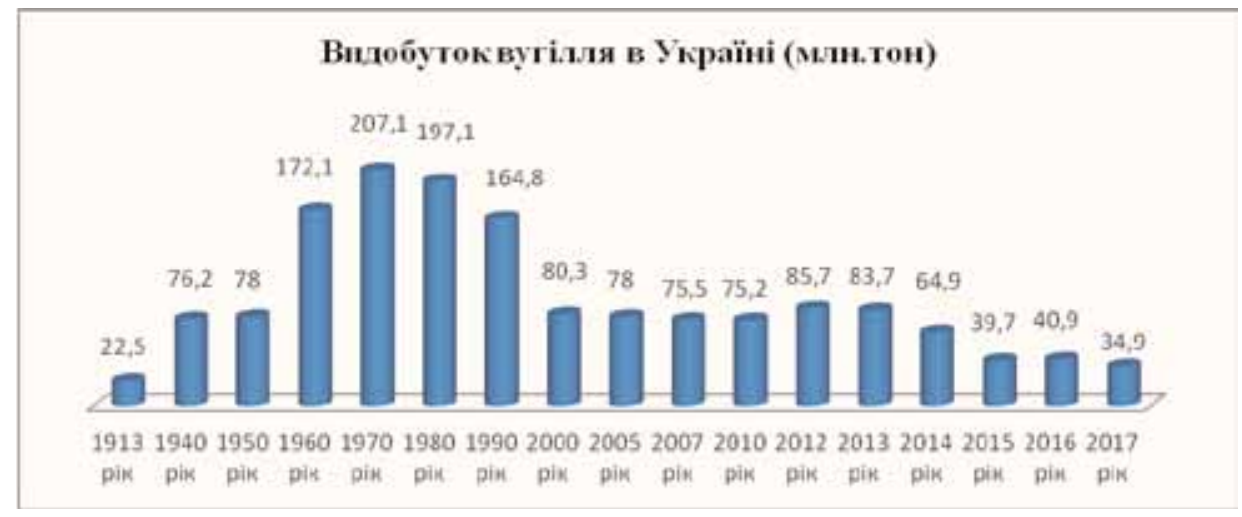

Рис. 3. Видобуток вугілля в Україні (млн тон) (розроблено автором за [6])

Вугілля прийде в Україну з Австралії, Південної Африки, Колумбії, Нової Зеландії та США. Та це не зміцнить енергетичної безпеки України, оскільки, по-перше, частина країн - це нестабільні регіони, 
по-друге, зростає затрата на доставку вугілля, а по-третє - якість такого вугілля нижча. Тобто в Україні зросла енергетична залежність і від даного ресурсу, та ще більше зросли енергетичні ризики. Варто повертатися до виробництва вугілля в історичних місцях його видобутку в Україні.

У зв’язку із виходом із виробничого циклу нафтопереробних заводів України - Луганського, Одеського, Надвірнянського та майже на половину Кременчуцького і значним зниженням видобутку нафти, зокрема світлої, виробництво як і всіх решти енергоносіїв за півстоліття скоротилося в шість разів (рис. 4). Як наслідок, ціни на пальне в Україні вже обігнали ціну долара, саме так раніше пояснювали нафтотрейдери коливання ціни на нафту. Хоча ціна на нафту протягом останніх 5-7 років падає, а ціна бензину А-95 перейшла межу 31 грн/літр, що ближче до курсу євро в Україні. Водночас як у Росії та багатьох Європейських країнах ціна такого пального вдвічі нижча.

Це особливий ресурс, який своєю ціною тисне на загальне ціноутворення на ринку України, це, насамперед, помітно на продовольчому ринку, коли ціни на пальне для аграріїв значно зросли, а значить працювати собі у збиток ніхто не буде.

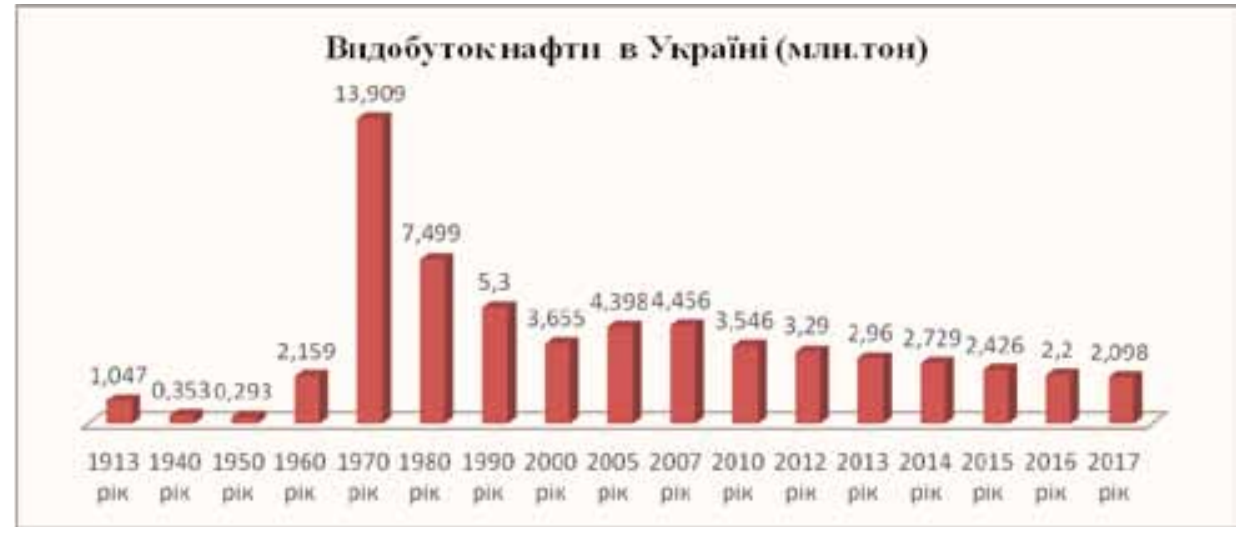

Рис. 4. Видобуток нафти в Україні (млн тон) (розроблено автором за [6])

Україна має достатньо нерозвіданих і не розроблених родовищ, але бажання бізнесу, зокрема і тіньового не освоювати родовища, а здійснювати видобуток і продаж нафти за високими цінами, що не сприяє насиченню ринку енергоресурсами. I тоді, коли станом на 28.05.2018 року, світові ціни на нафту впали до мінімумів, пробивши вниз психологічну позначку в 75 доларів за барель. Так, котирування липневих ф'ючерсів на еталонну марку Brent на лондонській біржі ICE Futures впали до 75,56 долара за барель. Водночас котирування протягом дня вже падали нижче 75 доларів - до 74,87 долара [7].

Енергетична залежність України вже привела до значного падіння життєвого рівня населення та зростання міграції населення i, насамперед, трудової міграції.

Як видно з таблиці 1, тарифи на електроенергію в Україні у 2017 році - одні з найнижчих у Європі, але співставлення розміру середньої зарплати і тарифу на електроенергію в Україні та у країнах Свропи, підтвердило, що платять українці одну з найбільших сум у Європі у відсотковому співвідношенні. Тариф на електроенергію в Україні - 1,68 грн/кВт. Дешевше тільки в Росії - 1,52 грн/кВт. Третій за розміром тариф на енлктрику в Європі - у Болгарії (2,95 грн/кВт). Найдорожче коштує електроенергія в Німеччині і Данії - понад 9 грн/кВт.

Та під час аналізу розміру середньої зарплати, з'ясовується, що тут Україна займає вагоме останнє місце серед країн Європи. За даними Держстату, українці в середньому заробляли у 2017 році 7339 грн/ міс. [6]. Якщо поглянути в таблиці на антилідерів цього показника, то з'ясується, що в останній трійці за розміром зарплати - знову Росія (14044 грн.) та Болгарія (12736 грн.). А в країнах із найвищими цінами на електроенергію зарплати становлять понад 50 тисяч грн. Зокрема, в Данії - рекордсмена за тарифом на електроенергію - працівники зароблять у середньому 70 тисяч гривень.

Незважаючи на те, що тариф на електроенергію в Україні один із найнижчих у Європі й одночасно найнижча середня зарплата, то, як бачимо з таблиці 1, українець із тарифом 1,68 грн/кВт витрачає на електроенергію 3,43\% місячної зарплати, водночас громадянин Данії з тарифом 9,51 грн/кВт витрачає у 2,3 рази менше - 1,47\% від зарплати. Найменше ж на електроенергію серед європейських країн, що зазначені в таблиці 1 , витрачають у Люксембурзі - $0,83 \%$.

Зрозуміло, що розроблення механізму міжрегіональної енергетичної інтеграції вимагає врахування інтересів власників енергетичного бізнесу. Необхідно розробити низку нормативних актів, що дають змогу нівелювати можливе зниження прибутковості енергетичного бізнесу, що виник через наявність територіальних преференцій [9]. 
Таблиияя 1

Співвідношення основних показників використання енергоносіїв і доходів громадян в Україні та країнах Свропи (в грн) [6], [8]

\begin{tabular}{|c|c|c|c|c|c|c|}
\hline \multirow[b]{2}{*}{$\begin{array}{l}\text { № } \\
\text { 3/II }\end{array}$} & \multirow[b]{2}{*}{ Країна } & \multirow[b]{2}{*}{$\begin{array}{l}\text { Середня заро- } \\
\text { бітна плата }\end{array}$} & \multirow[b]{2}{*}{$\begin{array}{c}\text { Ціна газу на } \\
\text { споживання на- } \\
\text { селенням }\end{array}$} & \multicolumn{3}{|c|}{ Електроенергія } \\
\hline & & & & $\begin{array}{c}\text { Тарифи } 1 \text { квт/ } \\
\text { год }\end{array}$ & $\begin{array}{c}\text { Вартість } 150 \text { квт/ } \\
\text { год (у \% до місячної } \\
\text { зарплати) } \\
\end{array}$ & $\begin{array}{c}\text { Середня вартість } \\
\text { для населення (1 } \\
\text { квт/год у\$) }\end{array}$ \\
\hline 1 & Австрія & 89362,67 & 22,25 & 6,25 & 1,49 & 0,24 \\
\hline 2 & Бельгія & 78910,57 & 17,61 & 7,81 & 1,79 & 0,35 \\
\hline 3 & Болгарія & 12736,07 & 13,00 & 2,95 & 3,48 & 0,12 \\
\hline 4 & $\begin{array}{c}\text { Велика Бри- } \\
\text { танія } \\
\end{array}$ & 79690,87 & 16,42 & 6,00 & 1,36 & 0,22 \\
\hline 5 & Греція & 29707,39 & 19,15 & 5,42 & 2,73 & 0,24 \\
\hline 6 & Данія & 69790,15 & 30,14 & 9,51 & 1,47 & 0,38 \\
\hline 7 & Естонія & 29644,65 & 18,06 & 3,72 & 1,88 & 0,15 \\
\hline 8 & Ірландія & 77922,05 & 20,79 & 7,11 & 1,38 & 0,27 \\
\hline 9 & Іспанія & 58900.27 & 21,35 & 6,74 & 1,88 & 0,29 \\
\hline 10 & Італія & 63570,12 & 24,05 & 7,42 & 2,01 & 0,27 \\
\hline 11 & Латвія & 22053,11 & 12,38 & 5,02 & 3,41 & 0,20 \\
\hline 12 & Литва & 28834,16 & 13,75 & 3,78 & 2,84 & 0,14 \\
\hline 13 & Люксембург & 94392,33 & 13,81 & 5,23 & 0,83 & 0,19 \\
\hline 14 & Молдова & 11388,29 & 6,78 & 3,48 & 1,85 & 0,12 \\
\hline 15 & Німеччина & 71209,90 & 19,93 & 9,14 & 1,93 & 0,38 \\
\hline 16 & Нідерланди & 70990,31 & 21,48 & 4,99 & 1,05 & 0,19 \\
\hline 17 & Польща & 23590,24 & 13,78 & 4,10 & 2,61 & 0,18 \\
\hline 18 & Португалія & 30866,08 & 27,27 & 7,23 & 3,51 & 0,28 \\
\hline 19 & Росія & 14044,00 & 2,09 & 1,52 & 1,41 & 0,08 \\
\hline 20 & Румунія & 24804,86 & 9,09 & 3,88 & 3,60 & 0,15 \\
\hline 21 & Сербія & 11466,39 & 9,53 & 3,95 & 3,46 & 0,08 \\
\hline 22 & Словаччина & 23870,29 & 14,18 & 5,35 & 2,77 & 0,18 \\
\hline 23 & Словенія & 33691,38 & 19,03 & 4,99 & 2,22 & 0,18 \\
\hline 24 & Угорщина & 35724,71 & 10,27 & 3,41 & 2,62 & 0,14 \\
\hline 25 & Україна & 8382,68 & 6,96 & 1,68 & 3,43 & 0,05 \\
\hline 26 & Фінляндія & 83200,59 & 7,67 & 4,74 & 0,90 & 0,20 \\
\hline 27 & Франція & 75036,46 & 20,58 & 5,20 & 1,15 & 0,21 \\
\hline 28 & Хорватія & 24845,04 & 12,38 & 4,03 & 2,43 & 0,15 \\
\hline 29 & Чехія & 26256,69 & 18,09 & 4,37 & 2,50 & 0,18 \\
\hline 30 & Швеція & 78598,09 & 72,53 & 5,81 & 1,13 & 0,24 \\
\hline
\end{tabular}

Висновки. Отже, основною метою функціонування системи забезпечення енергетичної безпеки $є$ підвищення стану захищеності від загроз надійному забезпеченню в кожний конкретний час обгрунтованих потреб економіки країни в паливі й енергії відповідної якості та в повному обсязі.

У сучасних умовах для забезпечення енергетичної безпеки основні споживачі і виробники енергоресурсів дотримуються таких стратегій: розвиток сектора сланцевих вуглеводнів, який сприятиме нарощуванню власному видобутку, скороченню імпорту нафти і газу; збільшення в енергобалансі долі відновлюваних джерел енергії, що дає можливість імпортерам знизити залежність від зовнішніх поставників, а експортерам - задовольнити попит і збільшити експорт завдяки вивільненню обсягів вуглеводного типу; впровадження енергоефективних технологій для оптимізації споживання та сприяння боротьбі з екологічними загрозами.

Різне поєднання вказаних стратегій буде характерним для країн, залежно від стану і напрямів забезпечення їх енергетичної безпеки.

\section{Література:}

1. Бобров С. А. Енергетична безпека держави. Київ, Ун-т економіки та права, ВНЗ «КРОК». 2013. 306 с.

2. Примаков Е. М. Мир без России? К чему ведёт политическая близорукость. М, Российская газета, 2009. 239 c.

3. Гройсман розповів, скільки газу щорічно добувають в Україні. URL: https://www.ukrinform.ua/rubriceconomy/2048715-grojsman-rozpoviv-skilki-gazu-soricno-dobuvaut-v-ukraini.html (дата звернення 18.03.2018).

4. Україна збільшила газові запаси в сховищах до третини. URL: https://biz.nv.ua/ukr/economics/ukrajinazbilshila-hazovi- zapasi-v-skhovishchakh-do-tretini-2472540.html (дата звернення 27.05.2018). 
5. Скільки грошей Україна недоотримала від транзиту. URL: https://www.ukrinform.ua/rubriceconomy/2416591-vitrenko-skazav-skilki-ukraina-nedootrimala-vid-tranzitu-rosijskogo-gazu.html (дата звернення 25.05.2018).

6. Держстат України. URL: http://www.ukrstat.gov.ua/ (дата звернення 27.05.2018).

7. Ціни на нафту рекордно впали: що буде далі. URL: https://narodna-pravda.ua/2018/05/28/tsini-na-nafturekordno-vpali-shho-bude-dali/ (28.05.2018. дата звернення).

8. Свростат. URL: http://ec.europa.eu/eurostat (дата звернення 25.05.2018).

9. Свірчевська Ю. Сутність енергетичної безпеки країни та чинники, що на неї впливають. URL: geopolitika. crimea.edu/ archive/.../042svirch.pdf. (дата звернення 14.03.2017). 